Published in final edited form as:

Toxicol Appl Pharmacol. 2007 November 1; 224(3): 337-349.

\title{
Chemoprevention of esophageal squamous cell carcinoma
}

\author{
Gary D. Stoner ${ }^{*}$, Li-Shu Wang, and Tong Chen \\ Division of Hematology and Oncology, Department of Internal Medicine, Ohio State University \\ College of Medicine and Comprehensive Cancer Center, Columbus, OH 43210
}

\begin{abstract}
Esophageal squamous cell carcinoma (SCC) is responsible for approximately one-sixth of all cancerrelated mortality worldwide. This malignancy has a multifactorial etiology involving several environmental, dietary and genetic factors. Since esophageal cancer has often metastasized at the time of diagnosis, current treatment modalities offer poor survival and cure rates. Chemoprevention offers a viable alternative that could well be effective against the disease. Clinical investigations have shown that primary chemoprevention of this disease is feasible if potent inhibitory agents are identified. The Fischer 344 (F-344) rat model of esophageal SCC has been used extensively to investigate the biology of the disease, and to identify chemopreventive agents that could be useful in human trials. Multiple compounds that inhibit tumor initiation by esophageal carcinogens have been identified using this model. These include several isothiocyanates, diallyl sulfide and polyphenolic compounds. These compounds influence the metabolic activation of esophageal carcinogens resulting in reduced genetic (DNA) damage. Recently, a few agents have been shown to inhibit the progression of preneoplastic lesions in the rat esophagus into tumors. These agents include inhibitors of inducible nitric oxide synthase (iNOS), cyclooxygenase-2 (COX-2), vascular endothelial growth factor (VEGF) and c-Jun [a component of activator protein-1 (AP-1)]. Using a food based approach to cancer prevention, we have shown that freeze-dried berry preparations inhibit both the initiation and promotion/progression stages of esophageal SCC in F-344 rats. These observations have led to a clinical trial in China to evaluate the ability of freeze-dried strawberries to influence the progression of esophageal dysplasia to SCC.
\end{abstract}

\section{Keywords}

esophagus; squamous cell carcinoma; chemoprevention; rat; human

\section{Introduction}

Esophageal cancer in humans occurs worldwide with a variable geographic distribution and ranks sixth as a cause of cancer mortality (Parkin et al., 2001). There are two main types of esophageal cancer with distinct etiological and pathological characteristics, squamous cell carcinoma (SCC) and adenocarcina. Esophageal SCC is the predominant type of esophageal malignancy worldwide, although adenocarcinomas are more prevalent in the USA (Souza, 2002). Epithelial dysplasia, characterized by an accumulation of atypical cells with nuclear hyperchromasia, abnormally clumped chromatin and loss of polarity, is the principal precursor lesion of esophageal SCC (Krasna and Wolfer, 1996). Esophageal SCC develops through a

\footnotetext{
*Corresponding author: Gary D. Stoner, Ph.D., Division of Hematology and Oncology, Department of Internal Medicine, Innovation Centre, 2001 Polaris Parkway, Columbus, OH 43240. Tel: (614) 293-3268; Fax: (614) 293-5952; E-mail: gary.stoner@ osumc.edu

Publisher's Disclaimer: This is a PDF file of an unedited manuscript that has been accepted for publication. As a service to our customers we are providing this early version of the manuscript. The manuscript will undergo copyediting, typesetting, and review of the resulting proof before it is published in its final citable form. Please note that during the production process errors may be discovered which could affect the content, and all legal disclaimers that apply to the journal pertain.
} 
progressive sequence from mild to severe dysplasia, carcinoma in situ and, finally, invasive carcinoma (Anani et al., 1991; Kuwano et al., 1993; Shu et al., 1981). The tumors present as fungating, ulcerating or infiltrating lesions in the esophageal epithelium. Most esophageal cancer patients present with advanced metastatic disease at the time of diagnosis (Layke and Lopez, 2006). This results in a poor prognosis; only 1 in 5 esophageal cancer patients survive more than 3 years after initial diagnosis (Polednak, 2003; Younes et al., 2002).

\section{Epidemiology of esophageal SCC}

The incidence of esophageal SCC shows marked variation in its geographic distribution and occurs at very high frequencies in certain parts of China, Iran, South Africa, Uruguay, France, Italy and Puerto Rico (Krasna and Wolfer, 1996; Rose, 1973; Schottenfeld, 1984; Sons, 1987; Stoner and Gupta, 2001; Yang, 1980). One-half of all esophageal SCC in the world occurs in China. Areas located in the southern parts of the Taihang mountains on the borders of Henan, Shansi and Hopei provinces have among the highest incidence and mortality rates for esophageal SCC in the world. In Linxian county in Henan province, the age-adjusted mortality rates from esophageal SCC have been reported to be as high as 151/100,000 for males and 115/100,000 for females annually (Munoz and Buiatti, 1996). Studies in these high-risk areas point to specific environmental factors as etiological agents of this disease. Esophageal SCC is infrequent in individuals less than 40 years of age but beyond this, the incidence increases with each decade of life (Pickens and Orringer, 2003). Males have a 3- to 4-fold greater risk for developing esophageal SCC than females and, in the USA, African Americans have more than a 5-fold higher incidence of esophageal SCC than Caucasians (Pickens and Orringer, 2003).

\section{Etiology of esophageal SCC}

There are several factors involved in the etiology of esophageal SCC (Stoner and Gupta, 2001). The excessive use of tobacco is a principal risk factor for this disease (Layke and Lopez, 2006). Several tobacco carcinogens, including certain nitrosamines, polycyclic aromatic hydrocarbons and aromatic amines, and toxins, including aldehydes and phenols, may be causally related to esophageal cancer (Hecht and Stoner, 1996; Tuyns, 1982; Wynder and Bross, 1961). Alcohol consumption has been shown to further increase the risk for SCC of the esophagus among tobacco users (Tuyns, 1980). Consumption of salt-cured, salt-pickled and moldy food is also implicated in the development of this disease, because these foods are frequently contaminated with $N$-nitrosamine carcinogens and/or fungal toxins (Ribeiro et al., 1996). Research in China and South Africa provides evidence that $N$-nitroso compounds and their precursors are etiological factors for esophageal SCC in these high incidence areas (Li et al, 1986; Lu et al., 1991). $N$-nitrosomethylbenzylamine (NMBA), a potent esophageal carcinogen in the rat, and other nitrosamines, have been identified in the diets and gastric juice collected from subjects in Henan province, China. The detection of $O^{6}$-methylguanine in the DNA of normal esophageal tissue taken from esophageal cancer patients in China further substantiates the role of methylating nitrosamines in the development of esophageal cancer (Umbenhauer et al., 1985; Yang et al., 1992). In addition, contaminated foods often contain nitrates, nitrites and secondary and tertiary amines which act as precursors for the formation of nitrosamine carcinogens in the acidic conditions of the stomach (Hecht and Stoner, 1996).

Other factors associated with the etiology of esophageal SCC include vitamin and trace mineral deficiencies ( $\mathrm{Li}$ et al., 1986; Lu et al., 1991). Plasma levels of vitamins A, C and E tend to be lower in patients with esophageal cancer. Studies from high risk areas for esophageal SCC indicate an inverse relationship between esophageal cancer mortality and levels of zinc, selenium and other trace elements in foods (Stoner and Gupta, 2001). Lye ingestion, diets high in starch but low in fruits and vegetables, and radiation therapy have been linked to an increased 
risk for esophageal SCC (Freeman, 2004; Layke and Lopez, 2006). In addition, consumption of temperature hot beverages, such as tea, and fungal invasion in esophageal tissues leading to localized inflammation and irritation may be additional promoting factors for esophageal SCC (Li et al., 1984). Furthermore, diseases affecting the esophagus and nearby structures such as achalasia, previous head and neck cancer, and Plummer-Vision syndrome are associated with an increased risk for esophageal SCC (Layke and Lopez, 2006). Finally, a role for human papilloma virus (HPV) has also been suggested in the etiology of SCC of the esophagus (Togawa et al., 1994). To date, however, the exact role of HPV infections in the development of the disease has not been elucidated.

It is clear that multiple environmental factors lead to the occurrence and development of esophageal SCC. Environmental carcinogens are able to affect the genetic material of host cells inducing aberrant regulation of multiple genes in esophageal cells leading to uncontrolled growth and, ultimately, esophageal cancer. Molecular studies of human esophageal tumors have identified numerous genetic abnormalities (Lam, 2000; Mandard et al., 2000). Stoner and Gupta, 2001, summarized genetic changes observed in esophageal SCCs including: (i) alterations in tumor suppressor genes leading to altered DNA repair, cell proliferation and apoptosis; (ii) disruption of the $\mathrm{G}_{1} / \mathrm{S}$ cell cycle checkpoint and loss of cell cycle control; and, (iii) alterations in oncogene function leading to deregulation of cell signaling pathways. Unlike in tumors of the human lung, pancreas, skin and colon, mutational activation of the ras genes is a rare event in primary SCCs of human esophagus. Genetic alterations more commonly associated with esophageal SCCs include p53 mutations (Gao et al., 1994; Hollstein et al., 1991), loss of p16MST1 and/or p15 (Xing et al., 1999) and/or RARß (Xu et al., 1999, 2005), amplification of INT-2, EGFR, cyclin $\mathrm{D}_{1}$ and c-Myc (Guo et al., 1993; Hollstein et al., 1988; Jiang et al., 1993; Lu et al., 1988), and elevations in hTERT, BMP-6, iNOS, COX-2 (Hiyama et al., 1999; Raida et al., 1999; Tanaka et al., 1999; Zimmerman et al., 1999) and B-catenin levels (Kimura et al., 1999). In addition, loss of heterozygosity on chromosomes 1p, 3p, 4, 5q, $9,11 \mathrm{q}, 13 \mathrm{q}, 17 \mathrm{q}$ and 18 have frequently been observed in esophageal SCCs. These chromosome changes lead to a loss of putative tumor suppressor function (An et al., 2005; Mandard et al., 2000, Moodley et al., 2006).

More recently, a number of additional genetic alterations have been identified in human esophageal SCC including: enhanced expression of the transcription activator, NFKB (Yang et al., 2005); decreased expression of the tumor suppressor genes, loss of disabled-2 (DAB-2) (Anupam et al., 2006), N-myc downstream regulated gene-1 (NDRG1) (Ando et al., 2006), Smad 4 and E-cadherin; and, altered expression of apoptosis related genes including bcl-2, caspase 3, TRAIL, Fas-L and Fas (Chang et al., 2005). The epigenetic silencing of tumor suppressor genes such as RAS association domain family $1 \mathrm{~A}$ (RASSF1A) and fragile histidine triad (FHIT) genes has also been reported (Kuroki et al., 2003). One or several of these genetic alterations undoubtedly contribute to the growth and invasive/metastatic potential of esophageal SCCs.

\section{Prevention of Esophageal SCC}

One approach to the prevention of esophageal SCC is through changes in lifestyle, especially the avoidance of alcohol and tobacco use. Additional benefits may be realized by the elimination of high salt foods that may be contaminated with microbial toxins, nitrosamines and their precursors. The increased consumption of vegetables and fruit throughout the world, and especially in the high-risk areas for esophageal SCC, might also be expected to reduce the incidence and mortality from the disease. Significant educational efforts are necessary to inform populations of the major risk factors for the disease and steps they might take to reduce their risk. Chemoprevention is another feasible approach, and it may have special relevance in high incidence areas of the world where carcinogen exposure is high. Animal models provide 
an excellent opportunity to evaluate chemoprevention strategies against cancer. The rat has been used almost exclusively as an animal model for studies of the etiology, biology and chemoprevention of esophageal SCC. The remainder of this article discusses molecular alterations and chemoprevention approaches in the rat model and their relevance to human esophageal SCC.

\section{Rat esophageal tumor model}

Nitrosamine-induced tumorigenesis in the Fischer-344 rat has proven to be a valuable animal model for studies of the molecular biology and chemoprevention of esophageal SCC (Beer and Stoner, 1998; Hecht and Stoner, 1996; Stoner and Gupta, 2001). Several nitrosamines, including the food contaminant, $N$-nitrosomethylbenzylamine (NMBA), and the tobaccospecific nitrosamine, $N$-nitrosonornicotine (NNN), induce tumorigenesis in the rat esophagus (Figure 1) (Stoner and Gupta, 2001). NMBA is by far the most potent inducer of tumors in the rat esophagus. As for other nitrosamines, the first step in the metabolic activation of NMBA involves hydroxylation of the methylene carbon by esophageal cytochrome P450 enzymes (Figure 2) (Stoner and Gupta, 2001). This reaction produces an $\alpha$-hydroxy derivative which spontaneously decomposes to methyldiazohydroxide and benzaldehyde.

Methyldiazohydroxide leads to formation of a methylcarbonium ion, the ultimate electrophilic species that methylates guanine residues at the $\mathrm{N}^{7}$ and $\mathrm{O}^{6}$ positions. The $\mathrm{O}^{6}$-methylguanine adduct is particularly important for carcinogenesis since it is poorly repaired and leads to single base mispairing in DNA. Repeat NMBA dosing results in esophageal tumor formation within 15-20 weeks (Figure 3). Several preneoplastic lesions produced in NMBA-treated rat esophagus closely mimic lesions observed in the human disease. These lesions include simple hyperplasia, leukoplakia and epithelial dysplasia (Figure 4). It should be noted that squamous papilloma is the predominant tumor type seen in the rat esophagus model. This differs from humans in that papillomas are rarely observed in the human esophagus. The incidence of SCC in the rat esophagus is rather low since the animals often succumb to the occlusive effects of large papillomas in their esophagi before carcinomas can develop. In a typical tumor bioassay, subcutaneous administration of NMBA at either 0.25 or $0.5 \mathrm{mg} / \mathrm{kg}$ body weight three times per week for 5 weeks, or once per week for 15 weeks, results in a $100 \%$ tumor incidence by 25 weeks (Stoner and Gupta, 2001). On average, these two doses of NMBA will produce from 2-4 or 4-8 tumors per esophagus, respectively, at 25 weeks. In the past several years our laboratory and others have used this model to develop surrogate end-point biomarkers, identify novel targets for intervention and therapy and evaluate putative chemoprevention agents against esophageal SCC.

Genetic analyses of NMBA-induced rat esophageal tumors have identified multiple molecular events in the conversion of normal esophagus to cancer (Figure 5) (Stoner and Gupta, 2001). Mutations in oncogenes and tumor suppressor genes in rat esophageal tumors are most likely due to formation of methylated guanine adducts in esophageal DNA. In contrast to human esophageal tumors, a large majority, between 60 and 100\%, of NMBA-induced rat esophageal papillomas have a $\mathrm{G}: \mathrm{C} \rightarrow \mathrm{A}: \mathrm{T}$ transition mutation in codon 12 of the $\mathrm{H}$-ras gene (Lozano et al., 1994; Wang et al. 1990). One study indicated that $\mathrm{G} \rightarrow \mathrm{A}$ mutations in codon 12 of the gene occur at very low frequency in early premalignant lesions of the esophagus and increase proportionately in lesions that progress to papilloma (Liston et al., 2000). These data suggest that mutational activation of the H-ras gene is important for progression of the premalignant lesions to papillomas. Additional evidence in support of this concept is the observation that transgenic rats carrying the human c-Ha-ras proto-oncogene are highly susceptible to the induction of esophageal tumors with NMBA (Asamoto et al., 2002). As has been found in human esophageal tumors, $\mathrm{G}: \mathrm{C} \rightarrow \mathrm{A}: \mathrm{T}$ transition mutations have been observed in the $p 53$ tumor suppressor gene in $\sim 30 \%$ of rat esophageal papillomas (Lozano et al., 1994; Wang et al., 1996). These mutations have been found to be evenly distributed across the gene; no "hot- 
spots" were found for these mutations in the gene. In other studies, cyclin D1 and cyclin E mRNA levels were found to be elevated in NMBA-induced rat esophageal papillomas, and immunohistochemical staining revealed extensive nuclear staining for both $\mathrm{G}_{1}$ cyclins (Wang et al., 1996; Youssef et al., 1997). These observations suggest that cell cycle regulation is altered during rat esophageal tumorigenesis. Increased expression of EGFR and proliferating cell nuclear antigen (PCNA), deregulated expression of transforming growth factor $\beta 1$ and altered localization of E-cadherin and $\alpha$-catenin have also been documented in these tumors (Khare et al., 1999; Stoner and Gupta, 2001; Wang et al., 1996).

Recent studies in our laboratory have demonstrated elevated levels of COX-2 mRNA and $\mathrm{PGE}_{2}$ (Carlton et al., 2002), iNOS protein (Chen et al., 2004), and iNOS, COX-2, VEGF and c-Jun mRNA and protein (Chen et al., 2006; Chen et al., 2006) in preneoplastic lesions and in papillomas of NMBA-treated rat esophagus. The mRNA and protein levels of these genes increased with progression of the premalignant lesions to papillomas indicating that they play a functional role in esophageal tumorigenesis. This was further substantiated by direct correlations between COX-2, iNOS and VEGF mRNA and protein expression levels and the levels of $\mathrm{PGE}_{2}$, nitrate/nitrite and the number of microvessels, respectively, in esophageal tissues.

\section{Chemoprevention studies in rat esophagus}

Mechanistically, chemopreventive agents have been classified as either "blocking" agents or "suppressing" agents (Wattenberg, 1985). Blocking agents act at the initiation stage of carcinogenesis through their influence on the metabolism of carcinogens leading, ultimately, to reduced damage to cellular DNA. Suppressing agents act on the promotion/progression stages of carcinogenesis by influencing cell proliferation rates, apoptosis, differentiation, angiogenesis, tissue invasion, etc. Several compounds have been shown to inhibit the initiation and promotion/progression stages of esophageal carcinogenesis in the rat. These compounds and their actions are described below. However, it should be recognized that many of the compounds to be discussed act on both the initiation and promotion/progression stages of carcinogenesis and, thus, the classification below is, in part, one of convenience.

\section{Agents that inhibit tumor initiation in rat esophagus}

Chemoprevention studies in the rat esophagus model have identified several agents that inhibit tumor initiation (Table 1). Ellagic acid (EA), a naturally occurring polyphenol, when given in the diet at concentrations of 0.4 and $4.0 \mathrm{~g} / \mathrm{kg}$, significantly inhibits esophageal tumor development (Mandal and Stoner, 1990). EA inhibits the metabolic activation of NMBA into electrophillic species, and stimulates the activities of Phase II detoxifying enzymes (Barch and Fox, 1989;Mandal et al., 1988). Addition of 13-cis-retinoic acid to the diet antagonized the preventive effects of EA (Daniel and Stoner, 1991). Diallyl sulfide, a component of garlic that acts principally by stimulation of Phase II enzymes, was also found to be an effective inhibitor of NMBA-induced tumorigenesis in the rat esophagus (Brady et al., 1988;Wargovich et al., 1988). The polyphenolic fraction of black tea (theaflavins), as well as the major catechin in green tea, [(-)-epigallocatechin 3-gallate (EGCG)], had a modest effect on tumor multiplicity when administered in the drinking water (de Boer JG et al., 2004; Li et al., 2002; Morse et al., 1997). The mechanisms by which tea inhibited tumor initiation in these studies was not determined however, EGCG down-regulates early expressed genes (COX-2, cyclin D1) in esophageal carcinogenesis probably during NMBA treatment. Curcumin, a component of the spice, tumeric, at $500 \mathrm{ppm}$ in the diet inhibited both the initiation and post-initiation stages of NMBA-induced esophageal tumorigenesis (Ushida et al., 2000). Curcumin significantly decreased tumor development and the incidence and multiplicity of preneoplastic lesions. These effects correlated with reduced expression of cell proliferation markers (5-bromo-2'deoxyuridine labeling index) in the non-lesional esophageal epithelium. In a later report by the 
same laboratory, curcumin was shown to reduce the level of CYP2B1 in the rat esophagus and this was correlated with inhibition of the metabolic activation of NMBA (Mori et al., 2006). Thus, the modulating effect of curcumin on the initiation phase of esophageal carcinogenesis appears to be due, in part, to its effects on the metabolism of NMBA.

The most effective group of anti-initiating agents so far evaluated in the rat esophagus are the arylalkyl isothiocyanates (Figure 6). Phenethyl isothiocyanate (PEITC), found as a glucosinolate in many cruciferous vegetables, such as watercress, cauliflower, Brussels sprouts, cabbage, etc. is a potent inhibitor of the metabolic activation of nitrosamine carcinogens and DNA methylation in vivo and in vitro (Carlson et al., 1981;Hanley et al., 1983; Stoner et al., 1991). Dietary administration of PEITC at concentrations of $3.0 \mathrm{mmol} / \mathrm{kg}$ diet or greater completely inhibits NMBA-induced esophageal tumorigenesis in the rat (Stoner et al., 1991), and lower concentrations were also effective (Wilkinson et al., 1995). Since isothiocyanates of longer chain length were found to be more effective inhibitors of NNK tumorigenesis in the mouse lung (Morse et al., 1991), we examined the effect of alkyl chain length of isothiocyanates on inhibition of NMBA-induced tumorigenesis in rat esophagus. The inhibitory activity of the isothiocyanates was found to correlate with increasing side chain length. Phenylpropyl isothiocyanate (PPITC) was a more potent inhibitor than PEITC, whereas benzyl isothiocyanate (BITC), a shorter chain length isothiocyanate, was less active.

Reductions in NMBA-induced $O^{6}$-methylguanine levels in esophageal DNA following dietary administration of the isothiocyanates correlated with their relative ability to inhibit tumor incidence and multiplicity (Wilkinson et al., 1995). PPITC was also able to effectively inhibit another important esophageal carcinogen, the tobacco-specific nitrosamine NNN, when provided in the rat diet (Stoner et al., 1998). Interestingly, phenylbutyl isothiocyanate (PBITC) was found to be less effective than PPITC and phenylhexyl isothiocyanate (PHITC) actually enhanced the tumor response to NMBA (Stoner and Morse, 1997; Stoner et al., 1995, 1999; Wilkinson et al., 1995). The mechanism of this enhancement appears to be due to a cytotoxic effect of PHITC in the rat esophagus that results in increased cell proliferation (Hudson et al., 2001), and not due to either a stimulatory effect of PHITC on NMBA activation or an inhibitory effect of PHITC on DNA repair (Morse et al., 1997).

\section{Agents that inhibit tumor progression in rat esophagus}

An effective chemopreventive agent against human esophageal SCC should possess significant inhibitory activity when administered after carcinogen exposure (i.e., post-initiation). The reason for this is that a major subject population for chemoprevention of human esophageal SCC includes individuals who possess dysplastic esophageal lesions which can progress to esophageal SCC (Wang et al., 2005). Effective chemopreventive agents for this cohort would either regress these lesions or extend the latency period for their progression to SCC. To date, very few single compounds have been found to be effective in inhibiting the promotion/ progression stages of NMBA tumorigenesis in the rat esophagus (Table 2).

As indicated above, PEITC is a highly effective anti-initiation agent in the rat esophagus however, its usefulness for the human esophagus may be limited since it had no effects on NMBA tumorigenesis when administered post-initiation (Siglin et al., 1995). Similarly, EA had only a modest effect on esophageal tumorigenesis when administered post-initiation, and dietary sulindac, supplemental calciuim and selenium were ineffective (Hu et al., 1992; Siglin et al., 1995). Decaffeinated green tea and black tea were found to be effective in the postinitiation period, but only when given at very high concentrations (Wang et al., 1995). In more recent studies however, effective agents for preventing tumor progression in the rat esophagus when administered post-initiation have been identified. The synthetic compound, $S, S^{\prime}-1,4-$ phenylene-bis (1,2-ethanediyl)bis-isothiourea (PBIT), a selective iNOS inhibitor, reduced both tumor incidence and multiplicity in the rat esophagus when provided at 50 or $100 \mathrm{ppm}$ in the 
$\operatorname{diet}$ (Chen et al., 2004). PBIT reduced the production of NO in preneoplastic and papillomatous esophageal lesions when compared with comparable lesions in rats treated with NMBA only. L-748706, a selective COX-2 inhibitor, reduced tumor multiplicity in the rat esophagus when provided at 100 and $150 \mathrm{ppm}$ in the diet (Stoner et al., 2005). The compound was effective only when it reduced $\mathrm{PGE}_{2}$ levels in preneoplastic esophageal tissues approximately to levels found in normal, untreated esophagus. Resveratrol (Li et al., 2002), and JTE-522 (Li et al., 2001), a selective COX-2 inhibitor, both inhibited tumor development in NMBA-treated rat esophagus by reducing PGE $_{2}$ levels in the esophagus. Irinotecan hydrochloride (CPT-11), a potent anti-cancer drug with suppressive effects against gastric and colorectal cancers, exhibited anti-progression effects against esophageal tumorigenesis by reducing the proliferation rate of cells in NMBA-exposed squamous epithelium and preneoplastic lesions (Fujiwara et al., 2004).

Agents that either enhanced NMBA-tumorigenesis in the rat esophagus or had no effect-As indicated above, dietary PHITC enhanced NMBA-tumorigenesis in the rat esophagus and the mechanism appears to be due to a low-grade cytotoxic effect leading to increased proliferation of premalignant cells (Hudson et al., 2001). $N$-(4-hydroxyphenyl) retinamide (4-HPR), a synthetic amide of all-trans-retinoic acid, also significantly enhanced esophageal tumorigenesis (Gupta et al., 2001). At 0.4 and $0.8 \mathrm{gm} / \mathrm{kg}$ diet, 4-HPR increased tumor multiplicity by 2.4- and 3.7- fold, respectively. 4-HPR enhanced NMBA metabolism and DNA adduct formation, as well as increased tumor size. It also produced a marked stimulation in the growth rate of premalignant cells (data not published). Piroxicam, a potent COX inhibitor, was ineffective as an inhibitor of NMBA-tumorigenesis in the esophagus when administered in the diet at 200 and $400 \mathrm{ppm}$ (Carlton et al., 2002). Interestingly, piroxicam reduced $\mathrm{PGE}_{2}$ levels in NMBA-treated esophagus below those found in normal esophagus and still it was ineffective. The authors speculated that piroxicam may have failed to modulate additional biochemical pathways involved in NMBA-induced tumorigenesis. Perillyl alcohol, a monoterpene found in lavender, spearmint and fruit, had a weak promoting effect on NMBAtumorigenesis when added to the diet at 0.5 and $1 \%$ (Liston et al., 2003). Although the monoterpene has the potential to inhibit Ha-ras farnesylation, it did not affect Ras membrane localization in this study, and it produced an increase in nuclear and cytoplasmic vacuolization in basal epithelial cells. It is possible that this local toxic effect resulted in increased cellular proliferation and an enhancement of postinitiation effects by perillyl alcohol.

\section{Freeze-dried berries as preventative agents for the esophagus-Cancer}

chemoprevention using a "food-based" approach is emerging as an alternative to the use of single compounds. The addition of freeze-dried vegetables to the diet was shown to be effective in preventing tumor development in the rodent colon (Rijken et al., 1999). Other studies have documented the ability of whole foods, such as tomato juice, paprika juice, dry beans and soybeans, to inhibit carcinogenesis in animal models (Gotoh et al., 1998; Hughes et al., 1997; Melendez-Martinez et al., 2004; Narisawa et al., 2000, 1998; Okajima et al., 1988; Schaffer et al., 1996). Epidemiological studies suggest that the varied geographical distribution of human esophageal SCC throughout the world may be due, in part, to diets that are deficient in vegetables and fruit (Ribeiro et al., 1996). Based on these observations, our laboratory has developed a food-based approach for the prevention of esophageal cancer. While conducting studies with EA in the mid-1980's, we decided to identify foods in which EA might be found. We tested a series of fruits for their content of EA and found high concentrations (520 - 1,800 $\mu \mathrm{g} / \mathrm{g}$ dry weight) in black raspberries (BRB), red raspberries, strawberries (STRW) and cranberries (Daniel et al., 1989). Ellagic acid was found exclusively in the pulp and the seed of these fruits, it was not detected in the juice. Based upon these observations, we decided to freeze-dry (lyophilize) berries to increase the concentration of putative inhibitory agents in them since berries are composed of $85-90 \%$ water. After removal of the seeds through the use 
of a sieve, the berry pulp is then ground into a fine powder for subsequent administration to animals. In a series of experiments, we observed that both freeze-dried STRW and BRB powders, at 5 and $10 \%$ of the diet, inhibited NMBA-induced tumor initiation in the rat esophagus (Table 3) (Carlton et al., 2001; Kresty et al., 2001; Stoner et al., 1999). At 10\% of the diet, both STRW and BRB powders produced an approximate 50\% reduction in tumor multiplicity in the esophagus. This inhibition was similar to that seen in earlier experiments with pure EA, which initially led us to believe that the EA in the berries was responsible for their inhibitory effect. Analysis of the STRW diet indicated, however, that the EA content in a 10\% STRW diet is less than one-fifth of the EA we used in initial studies with pure EA. Thus, it became apparent that other components in berries; e.g., vitamins, minerals, other polyphenols, phytosterols, etc., might also be responsible for their cancer inhibitory effects (Stoner et al., 2006). The anti-initiation effects of berries correlated with their ability to reduce the formation of $O^{6}$-methylguanine adducts in esophageal DNA. In this regard, dietary berry powders and berry extracts have been shown to influence both the metabolic activation and detoxification of NMBA by the esophagus (Reen et al., 2006).

At the same dietary concentrations (5 and 10\%), STRW and BRB powders significantly reduced tumor multiplicity by more than $30 \%$ when administered in a post-initiation scheme indicating the ability of the berries to inhibit tumor progression in the esophagus (Carlton et al., 2001; Kresty et al., 2001; Stoner et al., 1999). In one study, BRB were found to reduce the PCNA labeling index in NMBA-treated esophagus indicating their ability to reduce the growth rate of preneoplastic cells (Kresty et al., 2001). More recently, we have shown that BRB downregulate NMBA-induced cyclooxygenase-2 (COX-2), inducible nitric oxide synthase (i-NOS), c-Jun, and vascular endothelial growth factor (VEGF) in the esophagus, and this correlated with reduced levels of $\mathrm{PGE}_{2}$, nitrate/nitrite, and microvessel density, respectively (Chen et al., 2006; Chen et al., 2006). The extent of COX-2 inhibition by BRB was similar to that observed with the specific COX-2 inhibitor, L-748706, indicating the potency of berries for downregulating COX-2. A more extensive description of the cancer inhibitory effects of berries for the rat esophagus is presented in a recent review article (Stoner, et al., 2006). Additional food substances that have been shown to inhibit NMBA-induced tumorigenesis in the rat esophagus are fermented brown rice and rice bran (Kuno et al., 2004). These foods inhibited the postinitiation stage of esophageal tumorigenesis by reducing the proliferation rate of premalignant cells.

\section{Chemoprevention of human esophageal squamous cell carcinoma}

An important component in chemoprevention of human esophageal SCC is that of blocking the progression of premalignant lesions, such as epithelial dysplasia, to malignant SCC (Wang et al., 2005). With the availability of endoscopic and cytological screening techniques, the identification and follow-up of esophageal dysplasia among high-risk populations has become possible. The use of "balloon cytology" coupled with endoscopy in China has proven useful in identifying individuals with premalignant lesions and improving their survival by clinical interventions. Individuals with identified premalignant lesions have also been subjects for clinical chemoprevention trials.

As has been seen in the rat model of esophageal SCC, studies in human cancer have found a relationship between the rate of cell proliferation and risk for esophageal SCC. Individuals at higher risk for esophageal SCC have a more rapid rate of cell proliferation in the superficial and intermediate layers of the esophageal epithelium (Munoz et al., 1985). Moreover, there is a positive correlation between increasing rates of cell proliferation and histological progression of premalignant lesions from hyperplasia to mild and moderate dysplasia (Wang et al., 1990). Thus, clinical trials have been conducted with candidate chemopreventive agents that may inhibit cell proliferation rates in the esophagus. The results of these studies have not been too 
encouraging. In a study amongst residents of Linxian, China, daily supplementation with vitamins and minerals were evaluated during a period of 30 months. Esophageal lesions previously diagnosed as acanthosis, esophagitis, squamous dysplasia and SCC were examined for rates of cell proliferation. At the end of the observation period, no treatment effect on the overall amount of squamous epithelial proliferation was found in any of the histological catagories (Rao et al., 1994). In another study, 200 subjects were given dietary supplementation of calcium (1200 mg/day) for 11 months (Wang, et al., 1993). This treatment did not result in reduced rates of cell proliferation in the esophageal epithelium in either hyperplastic or dysplastic lesions. Although cell proliferation rates were not measured, one study investigated the effects of antitumor-B (ATB; a mixture of Chinese herbs), a retinoid (4ethoxycarbophenylretinamide; 4-ECPR) and riboflavin supplementation in the diet of subjects diagnosed with mild or marked esophageal dysplasia in Hunan, China (Lin et al., 1990). The results revealed a significant reduction in cancer development from pre-existing dysplasia. ATB treatment for 3-5 years reduced the cancer development rate by 52 and $47 \%$, respectively. 4-ECPR lowered the clinical cancer rate by $37-43 \%$. The overall incidence of cancer was not affected in subjects supplemented with riboflavin. The exact composition of ATB and its mechanism of action against esophageal SCC remains to be determined. More recently, a randomized, placebo-controlled, esophageal squamous cell cancer chemoprevention trial evaluated selenomethionine ( $200 \mu \mathrm{g}$ daily) and celecoxib ( $200 \mathrm{mg}$ twice daily) given for 10 months in high-risk populations (Limburg et al., 2005). One rationale for the use of celecoxib, a COX-2 inhibitor, is that both dysplastic lesions and esophageal SCC have been found to overexpress COX-2 (Yu et al., 2004). Subjects had histologically confirmed mild or moderate esophageal dysplasia at baseline. Per subject change in the worst dysplasia grade was defined as the primary end-point. Overall, selenomethionine treatment resulted in a trend toward increased dysplasia regression (43 vs 32\%) and decreased dysplasia progression (14 vs 19\%). Celecoxib, a specific COX-2 inhibitor, did not influence changes in dysplasia grade overall. Interestingly, results from nine epidemiological studies ( 2 cohort and 7 case control), involving 1813 cases of esophageal cancer, suggest a protective effect between aspirin and other NSAIDs use and the occurrence of esophageal cancer (SCC and adenocarcinoma) (Corley et al., 2003). These results suggest that agents which inhibit COX-1 or both COX-1 and COX-2 might be more effective against esophageal cancer than specific inhibitors of COX-2.

Green tea has been shown to reduce tumor multiplicity in the rat esophagus when administered in the drinking water (de Boer et al., 2004). However, epidemiological studies of the relationship between green tea consumption and the occurrence of esophageal SCC have been inconclusive. In a recent study in Japan, the effects of smoking, alcohol use and green tea consumption on the risk of esophageal cancer in Japanese men were investigated (Ishikawa et al., 2006). Results from this study indicated that men who smoked, and consumed alcohol and green tea, were at increased risk for the development of esophageal SCC compared with men who had never smoked and consumed little or no alcohol or green tea. Green tea consumption did not appear to reduce the risk for esophageal cancer in users of tobacco and alcohol. A clinical trial conducted in a high-incidence area for esophageal SCC in China found that green tea was not effective in reducing rates of cell proliferation or alleviating the development of dysplastic lesions in the esophagus (Wang et al., 2002).

Our laboratory conducted a phase I trial in 11 normal subjects to determine the safety and tolerability of oral consumption of $45 \mathrm{~g}$ per day of freeze-dried black raspberries (BRB) for 1 week (Stoner et al., 2005). We also determined, for this dosing regimen, whether the four anthocyanins and ellagic acid in BRB might have sufficient bioavailability to be measurable in plasma and urine. Results of this study indicated that the BRB were well tolerated clinically. Maximum concentrations of anthocyanins and ellagic acid in plasma occurred at 1 to 2 hours, and in urine from 0 to 4 hours, following berry consumption. We concluded that $45 \mathrm{~g}$ of freezedried BRB daily are well tolerated by humans and, although the anthocyanins and ellagic acid 
are not well absorbed into the blood, their localized absorption into gastrointestinal tissues may be sufficient for protection against cancer. We have recently initiated a chemoprevention trial in a high-risk population in China to evaluate the ability of the berries to influence the development of dysplastic lesions.

\section{Conclusions}

The 5-year survival rate for esophageal SCC has not improved substantially in the past several decades in spite of advances in surgical techniques, radiotherapy and chemotherapy. Prevention is clearly and important approach to reduce the incidence and mortality from this disease. Lifestyle changes, especially the avoidance of tobacco and alcohol use, and the elimination of high salt and moldy foods, would reduce the incidence and mortality from the disease. In addition, the increased consumption of vegetables and fruit in the diet would provide sources of preventative agents and reduce known dietary deficiencies associated with development of the disease. Chemoprevention is another feasible approach. Special emphasis needs to be placed on the identification of additional molecular determinants in the development of esophageal SCC. Mechanistic studies using the F-344 rat model of esophageal carcinogenesis can provide important leads as to new targets for chemoprevention. In this regard, recent studies demonstrating the chemopreventive efficacy of agents that modulate the expression levels of iNOS, c-Jun (AP-1), COX-2 and VEGF in rat esophagus provide additional leads for agents that might be efficacious in humans. Studies in our laboratory indicate that compounds in freeze-dried berries modulate all of these molecular biomarkers, and probably many others. Thus, a food-based approach to the chemoprevention of this disease might also be effective.

\section{Abbreviations}

AP-1, activator protein-1; ATB, antitumor-B; BITC, benzyl isothiocyanate; BMP-6, bone morphogenetic protein 6; $\mathrm{BRB}$, freeze-dried black raspberries; $\mathrm{COX}-2$, cyclooxygenase-2; CYP2A3, cytochrome P450 2A3; CYP2E1, cytochrome P450 2E1; EA, ellagic acid; 4-ECPR, 4-ethoxycarbophenylretinamide; EGCG, (-)-epigallocatechin 3-gallate; EGFR, epidermal growth factor receptor; 4-HPR, $N$-(4-hydroxyphenyl)retinamide; HPV, human papilloma virus; hTERT, human telomerase reverse transcriptase; iNOS, inducible nitric oxide synthase; INT-2, fibroblast growth factor-3; NFkB, nuclear factor kappa B; NMBA, $N$ nitrosomethylbenzylamine; NNN, $N$-nitrosonornicotine; NO, nitric oxide; PBIT, S,S-1,4phenylene-bis(1,2-ethanediyl)bis-isothiourea; PBITC, phenylbutyl isothiocyanate; PCNA, proliferating cell nuclear antigen; PEITC, phenethyl isothiocyanate; PHITC, phenylhexyl isothiocyanate; PPITC, phenylpropyl isothiocyanate; RAR $\beta$, retinoic acid receptor beta; SCC, squamous cell carcinoma; STRW, freeze-dried strawberries; TRAIL, tumor necrosis factorrelated apoptosis-inducing ligand; VEGF, vascular endothelial growth factor.

\section{References}

An JY, Fan ZM, Gao SS, Zhuang ZH, Qin YR, Li JL, He X, Tsao GS, Wang LD. Loss of heterozygosity in multistage carcinogenesis of esophageal carcinoma at high-incidence area in Henan Province, China. World J Gastroenterol 2005;11:2055-2060. [PubMed: 15810068]

Anani PA, Gardiol D, Savary M, Monnier P. An extensive morphological and comparative study of clinically early and obvious squamous cell carcinoma of the esophagus. Pathol. Res. Pract 1991;187:214-219. [PubMed: 2068002]

Ando T, Ishiguro H, Kimura M, Mitsui A, Kurehara H, Sugito N, Tomoda K, Mori R, Takashima N, Ogawa R, Fujii Y, Kuwabara Y. Decreased expression of NDRG1 is correlated with tumor progression and poor prognosis in patients with esophageal squamous cell carcinoma. Dis Esophagus 2006;19:454458. [PubMed: 17069588] 
Anupam K, Tusharkant C, Gupta SD, Ranju R. Loss of disabled-2 expression is an early event in esophageal squamous tumorigenesis. World J Gastroenterol 2006;12:6041-6045. [PubMed: 17009406]

Asamoto M, Toriyama-Baba H, Ohnishi T, Naito A, Ota T, Ando A, Ochiya T, Tsuda H. Transgenic rats carrying human c-Ha-ras proto-oncogene are highly susceptible to $\mathrm{N}$-nitrosomethylbenzylamine induction of esophageal tumorigenesis. Jpn J Cancer Res 2002;93:744-751. [PubMed: 12149139]

Barch DH, Fox CC. Dietary ellagic acid reduces the esophageal microsomal metabolism of methylbenzylnitrosamine. Cancer Lett 1989;44:39-44. [PubMed: 2917341]

Beer DG, Stoner GD. Clinical models of chemoprevention for the esophagus. Hematol. Oncol. Clin. North Am 1998;12:1055-1077. [PubMed: 9888021]

Brady JF, Li DC, Ishizaki H, Yang CS. Effect of diallyl sulfide on rat liver microsomal nitrosamine metabolism and other monooxygenase activities. Cancer Res 1988;48:5937-5940. [PubMed: 3167846]

Carlson DG, Daxenbichler ME, VanEtten CH, Tookey ML, Williams PH. Glucosinolates in crucifer vegetables: turnips and rutabagas. J. Agric. Food. Chem 1981;29:1235-1241. [PubMed: 7320339]

Carlton PS, Gopalakrishnan R, Gupta A, Liston BW, Habib S, Morse MA, Stoner GD. Piroxicam is an ineffective inhibitor of N-nitrosomethylbenzylamine-induced tumorigenesis in the rat esophagus. Cancer Res 2002;62:4376-4382. [PubMed: 12154043]

Carlton PS, Kresty LA, Siglin JC, Morse MA, Lu J, Morgan C, Stoner GD. Inhibition of Nnitrosomethylbenzylamine-induced tumorigenesis in the rat esophagus by dietary freeze-dried strawberries. Carcinogenesis 2001;22:441-446. [PubMed: 11238184]

Chang MS, Lee HS, Lee BL, Kim YT, Lee JS, Kim WH. Differential protein expression between esophageal squamous cell carcinoma and dysplasia, and prognostic significance of protein markers. Pathol Res Pract 2005;201:417-425. [PubMed: 16136747]

Chen T, Stoner GD. Inducible nitric oxide synthase expression in $N$ - nitrosomethylbenzylamine (NMBA)-induced rat esophageal tumorigenesis. Mol. Carc 2004;40:232-240.

Chen T, Nines RG, Peschke SM, Kresty LA, Stoner GD. Chemopreventive effects of a selective nitric oxide synthase inhibitor on carcinogen-induced rat esophageal tumorigenesis. Cancer Res 2004;64:3714-3717. [PubMed: 15150132]

Chen T, Hwang H, Rose ME, Nines RG, Stoner GD. Chemopreventive properties of black raspberries in N-nitrosomethylbenzylamine-induced rat esophageal tumorigenesis: down-regulation of cyclooxygenase-2, inducible nitric oxide synthase, and c-Jun. Cancer Res 2006;66:2853-2859. [PubMed: 16510608]

Chen T, Rose ME, Hwang H, Nines RG, Stoner GD. Black raspberries inhibit Nnitrosomethylbenzylamine (NMBA)-induced angiogenesis in rat esophagus parallel to the suppression of COX-2 and iNOS. Carcinogenesis 2006;27:2301-2307. [PubMed: 16777990]

Corley DA, Kerlikowske K, Verma R, Buffler P. Protective association of aspirin/NSAIDs and esophageal cancer: a systematic review and meta-analysis. Gastroenterology 2003;124:47-56. [PubMed: 12512029]

Daniel EM, Krupnick AS, Heur YH, Blinzler JA, Nims RW, Stoner GD. Extraction, stability and quantitation of ellagic acid in various fruits and nuts. J. Food Comp. Anal 1989;2:338-349.

Daniel EM, Stoner GD. The effects of ellagic acid and 13-cis-retinoic-acid on Nnitrosomethylbenzylamine-induced esophageal tumorigenesis in rats. Cancer Lett 1991;56:117-124. [PubMed: 1998940]

de Boer JG, Yang H, Holcroft J, Skov K. Chemoprotection against N-nitrosomethylbenzylamine-induced mutation in the rat esophagus. Nutr Cancer 2004;50:168-173. [PubMed: 15623463]

Freeman HJ. Risk of gastrointestinal malignancies and mechanisms of cancer development with obesity and its treatment. Best Pract Res Clin Gastroenterol 2004;18:1167-1175. [PubMed: 15561645]

Fujiwara Y, Osugi H, Morimura K, Takemura M, Lee S, Hirohashi K, Fukushima S, Suehiro S. Suppressive effect of CPT-11 on rat esophageal tumorigenesis induced by Nnitrosomethylbenzylamine. Oncol Rep 2004;12:1169-1176. [PubMed: 15547733]

Gao H, Wang LD, Zhou Q, Hong JY, Huang TY, Yang CS. p53 tumor suppressor gene mutation in early esophageal precancerous lesions and carcinoma among high-risk populations in Henan, China. Cancer Res 1994;54:4342-4346. [PubMed: 8044781] 
Gotoh T, Yamada K, Yin H, Ito A, Kataoka T, Dohi K. Chemoprevention of N-methyl-N-nitrosourea induced rat mammary carcinogenesis by soy foods or biochanin A. Jpn. J. Cancer Res 1998;89:137142. [PubMed: 9548440]

Guo YJ, Lu H, Liang YY, He LZ, Wang H. Amplification of int-2 gene in primary esophageal carcinoma and fetal esophageal carcinoma induced by N-methyl-N-benzylnitrosamine. Chin. J. Oncol 1993;15:91-93.

Gupta A, Nines R, Rodrigo KA, Aziz RA, Carlton PS, Gray DL, Steele VE, Morse MA, Stoner GD. Effects of dietary N-(4-hydroxyphenyl)retinamide on N-nitrosomethylbenzylamine metabolism and esophageal tumorigenesis in the Fischer 344 rat. J Natl Cancer Inst 2001;93:990-998. [PubMed: 11438564]

Hanley AB, Heaney RK, Fenwick GR. Improved isolation of glucobrassicin and other glucosinolates. J. Sci. Food Agric 1983;34:869-874.

Hecht, SS.; Stoner, GD. Lung and esophageal carcinogenesis. In: Aisner, J.; Arriagada, R.; Green, MR.; Martini, N.; Perry, MC., editors. Comprehensive Textbook of Thoracic Oncology. Williams and Wilkins; Baltimore, MD: 1996. p. 25-50.

Hiyama T, Yokozaki H, Kitadai Y, Haruma K, Yasui W, Kajiyama G, Tahara E. Overexpression of human telomerase RNA is an early event in esophageal carcinogenesis. Virchows Arch 1999;434:483-487. [PubMed: 10394881]

Hollstein M, Peri L, Mandard AM, Welsh JA, Montesano R, Metcalf RA, Bak M, Harris CC. Genetic analysis of human esophageal tumors from two high incidence geographic areas: frequent p53 base substitutions and absence of ras mutations. Cancer Res 1991;51:4102-4106. [PubMed: 1855226]

Hollstein M, Smits AM, Galiana C, Yamasaki H, Bos JL, Mandard A, Partensky C, Montesano R. Amplification of EGF receptor gene but no evidence of ras mutations in primary human esophageal cancers. Cancer Res 1988;48:5119-5123. [PubMed: 3044581]

Hu G, Han C, Wild CP, Hall J, Chen J. Lack of effects of selenium on N-nitrosomethylbenzylamineinduced tumorigenesis, DNA methylation and oncogene expression in rats and mice. Nutr. Cancer 1992;18:287-295. [PubMed: 1296202]

Hudson TS, Carlton PS, Gupta A, Stoner GD, Morse MA. Investigation of the enhancement of NMBAinduced esophageal tumorigenesis by 6-phenylhexyl isothiocyanate. Cancer Lett 2001;162:19-26. [PubMed: 11121858]

Hughes JS, Ganthavorn C, Wilson-Sanders S. Dry beans inhibit azoxymethane-induced colon carcinogenesis in F344 rats. J. Nutr 1997;127:2328-2333. [PubMed: 9405582]

Ishikawa A, Kuriyama S, Tsubono Y, Fukao A, Takahashi H, Tachiya H, Tsuji I. Smoking, alcohol drinking, green tea consumption and the risk of esophageal cancer in Japanese men. J Epidemiol 2006;16:185-192. [PubMed: 16951537]

Jiang W, Zhang YJ, Kahn MC, Hollstein RM, Santella SH, Lu SH, Harris CC, Montesano R. Altered expression of the cyclin D1 and retinoblastoma genes in human esophageal cancer. Proc. Natl Acad. Sci. USA 1993;90:9026-9030. [PubMed: 8415648]

Khare L, Sabourin CLK, Young BRD, Jamasbi RJ, Stoner GD. Altered localization of E-cadherin and $\alpha$-catenin in rat esophageal tumors. Int. J. Oncol 1999;14:33-40. [PubMed: 9863006]

Kimura Y, Shiozaki H, Doki Y, Yamamoto M, Utsunomiya T, Kawanishi K, Fukuchi N, Inoue M, Tsujinaka T, Monden M. Cytoplasmic ß-catenin in esophageal cancers. Int. J. Cancer Pred. Oncol 1999;84:174-178.

Krasna, MJ.; Wolfer, RS. Esophageal carcinoma: diagnosis, evaluation and staging. In: Aisner, J.; Arriagada, R.; Green, MR.; Martini, N.; Perry, MC., editors. Comprehensive Textbook of Thoracic Oncology. Williams and Wilkins; Baltimore, MD: 1996. p. 563-584.

Kresty LA, Morse MA, Morgan C, Carlton PS, Lu J, Gupta A, Blackwood M, Stoner GD. Chemoprevention of esophageal tumorigenesis by dietary administration of lyophilized black raspberries. Cancer Res 2001;61:6112-6119. [PubMed: 11507061]

Kuno T, Hirose Y, Hata K, Kato K, Qiang SH, Kitaori N, Hara A, Iwasaki T, Yoshimura T, Wada K, Kobayashi H, Mori H. Preventive effect of fermented brown rice and rice bran on Nnitrosomethylbenzylamine-induced esophageal tumorigenesis in rats. Int J Oncol 2004;25:1809_ 1815. [PubMed: 15547721] 
Kuroki T, Trapasso F, Yendamuri S, Matsuyama A, Alder H, Mori M, Croce CM. Allele loss and promoter hypermethylation of VHL, RAR-beta, RASSF1A, and FHIT tumor suppressor genes on chromosome $3 p$ in esophageal squamous cell carcinoma. Cancer Res 2003;63:3724-3728. [PubMed: 12839965]

Kuwano H, Watanabe M, Sadanaga N, Ikebe M, Mori M, Sugimachi K. Squamous epithelial dysplasia associated with squamous cell carcinoma of the esophagus. Cancer Lett 1993;72:141-147. [PubMed: 8402583]

Lam AKY. Molecular biology of esophageal squamous cell carcinoma. Crit. Rev. Oncol. Hematol 2000;33:71-90. [PubMed: 10737369]

Layke JC, Lopez PP. Esophageal cancer: a review and update. Am Fam Physician 2006;73:2187-2194. [PubMed: 16836035]

Li MH, Ji C, Cheng SJ. Occurrence of nitroso compounds in fungi-contaminated foods: a review. Nutr. Cancer 1986;8:63-69. [PubMed: 3520493]

Li, MN.; Cheng, SJ. Etiology of carcinoma of the esophagus. In: Huang, GJ.; Kai, WY., editors. Carcinoma of the Esophagus and Gastric Cardia. Springer-Verlag; Berlin, Germany: 1984. p. 26-51.

Li ZG, Hong T, Shimada Y, Komoto I, Kawabe A, Ding Y, Kaganoi J, Hashimoto Y, Imamura M. Suppression of N-nitrosomethylbenzylamine (NMBA)-induced esophageal tumorigenesis in F344 rats by resveratrol. Carcinogenesis 2002;23:1531-1536. [PubMed: 12189197]

Li ZG, Shimada Y, Kawabe A, Sato F, Maeda M, Komoto I, Hong T, Ding Y, Kaganoi J, Imamura M. Suppression of N-nitrosomethylbenzylamine (NMBA)-induced esophageal tumorigenesis in F344 rats by JTE-522, a selective COX-2 inhibitor. Carcinogenesis 2001;22:547-551. [PubMed: 11285187]

Li ZG, Shimada Y, Sato F, Maeda M, Itami A, Kaganoi J, Komoto I, Kawabe A, Imamura M. Inhibitory effects of epigallocatechin-3-gallate on N-nitrosomethylbenzylamine-induced esophageal tumorigenesis in F344 rats. Int J Oncol 2002;21:1275-1283. [PubMed: 12429978]

Limburg PJ, Wei W, Ahnen DJ, Qiao Y, Hawk ET, Wang G, Giffen CA, Wang G, Roth MJ, Lu N, Korn EL, Ma Y, Caldwell KL, Dong Z, Taylor PR, Dawsey SM. Randomized, placebo-controlled, esophageal squamous cell cancer chemoprevention trial of selenomethionine and celecoxib. Gastroenterology 2005;129:863-873. [PubMed: 16143126]

Lin P, Zhang J, Rong Z, Han R, Xu S, Gao R, Ding Z, Wang J, Feng H, Cao S. Studies on medicamentous inhibitory therapy for esophageal precancerous lesions--3- and 5-year inhibitory effects of antitumorB, retinamide and riboflavin. Proc Chin Acad Med Sci Peking Union Med Coll 1990;5:121-129. [PubMed: 2098764]

Liston BW, Gupta A, Nines R, Carlton PS, Kresty LA, Harris GK, Stoner GD. Incidence and effects of Ha-ras codon $12 \mathrm{G} \rightarrow \mathrm{A}$ transition mutations in preneoplastic lesions induced by $\mathrm{N}$ nitrosomethylbenzylamine (NMBA) in the rat esophagus. Mol. Carc 2001;32:1-8.

Liston BW, Nines R, Carlton PS, Gupta A, Aziz R, Frankel W, Stoner GD. Perillyl alcohol as a chemopreventive agent in N-nitrosomethylbenzylamine-induced rat esophageal tumorigenesis. Cancer Res 2003;63:2399-2403. [PubMed: 12750258]

Lozano JC, Nakazawa H, Cros MP, Cabral R, Yamasaki H. G to A mutations in p53 and Ha-ras genes in esophageal papillomas induced by N-nitrosomethylbenzylamine in two strains of rats. Mol. Carcinog 1994;9:33-39. [PubMed: 8297483]

Lu, SH.; Chui, SX.; Yang, WX.; Hu, XN.; Guo, LP.; Li, FM. Relevance of N-nitrosamines to esophageal cancer in China. In: O’Neill, IK.; Chen, J.; Bartsch, H., editors. Relevance to Human Cancer of Nnitroso Compounds, Tobacco Smoke and Mycotoxin. IARC; Lyon: 1991. p. 11-17.IARC Scientific Publications no. 105

Lu SH, Hsieh LL, Luo FC, Weinstein IB. Amplification of the EGF receptor and c-myc genes in human esophageal cancers. Int. J. Cancer 1988;42:502-505. [PubMed: 2459070]

Mandal S, Shivapurkar NM, Galati AJ, Stoner GD. Inhibition of N-nitrosomethylbenzylamine metabolism and DNA binding in cultured rat esophagus by ellagic acid. Carcinogenesis 1988;9:13131316. [PubMed: 3383347]

Mandal S, Stoner GD. Inhibition of N-nitrosomethylbenzylamine-induced esophageal tumorigenesis in rats by ellagic acid. Carcinogenesis 1990;11:55-61. [PubMed: 2295128]

Mandard AM, Hainaut P, Hollstein M. Genetic steps in the development of squamous cell carcinoma of the esophagus. Mutat. Res 2000;462:335-342. [PubMed: 10767643] 
Melendez-Martinez AJ, Vicario IM, Heredia FJ. Nutritional importance of carotenoid pigments. Arch Latinoam Nutr 2004;54:149-154. [PubMed: 15586682]

Moodley R, Reddi A, Chetty R, Naidoo R. Abnormalities of chromosome 17 in oesophageal cancer. J Clin Pathol. 2006[Epub ahead of print]

Mori Y, Tatematsu K, Koide A, Sugie S, Tanaka T, Mori H. Modification by curcumin of mutagenic activation of carcinogenic N-nitrosamines by extrahepatic cytochromes P-450 2B1 and 2E1 in rats. Cancer Sci 2006;97:896-904. [PubMed: 16805852]

Morse MA, Kresty LA, Steele VE, Kelloff GJ, Boone CW, Balentine DA, Harbowy ME, Stoner GD. Effects of theaflavins on N-nitrosomethylbenzylamine-induced esophageal tumorigenesis. Nutr. Cancer 1997;29:7-12. [PubMed: 9383778]

Morse MA, Eklind KI, Hecht SS, Jordan KG, Choi CI, Desai DH, Amin SG, Chung FL. Structure-activity relationships for inhibition of 4-(methylnitrosamino)-1-(3-pyridyl)-1-butanone lung tumorigenesis by arylalkyl isothiocyanates in A/J mice. Cancer Res 1991;51:1846-1850. [PubMed: 2004368]

Morse MA, Lu J, Gopalakrishnan R, Peterson LA, Wani G, Stoner GD. Mechanism of enhancement of esophageal tumorigenesis by 6-phenylhexyl isothiocyanate. Cancer Lett 1997;112:119-125. [PubMed: 9029177]

Munoz N, Buiatti E. Chemoprevention of oesophageal cancer. IARC Sci Publ 1996;136:27-33. [PubMed: 8791112]

Munoz N, Lipkin M, Crespi M, Wahrendorf J, Grassi A, Lu SH. Proliferative abnormalities of the esophageal epithelium in Chinese populations at high and low risk for esophageal cancer. Int. J. Cancer 1985;36:187-189. [PubMed: 4018912]

Narisawa T, Fukaura Y, Hasebe M, Nomura S, Oshima S, Sakamoto H, Inakuma T. Prevention of Nmethylnitrosourea-induced colon carcinogenesis in rats by oxygenated carotenoid capsanthin and capsanthin-rich paprika juice. Proc. Soc. Exp. Biol. Med 2000;224:116-122. [PubMed: 10806419]

Okajima E, Tsutsumi M, Ozono S, Akai H, Denda A, Nishino H, Oshima S, Sakamoto H, Konishi Y. Inhibitory effect of tomato juice on rat urinary bladder carcinogenesis after N-butyl-N-(4hydroxybutyl)nitrosamin initiation. Jpn. J. Cancer. Res 1988;89:22-26. [PubMed: 9510471]

Parkin DM, Bray FI, Devesa SS. Cancer burden in the year 2000. The global picture. Eur J Cancer 2001;37:S4-S66. [PubMed: 11602373]

Pickens A, Orringer MB. Geographical distribution and racial disparity in esophageal cancer. Ann Thorac Surg 2003;76:S1367-S1369. [PubMed: 14530066]

Polednak AP. Trends in survival for both histologic types of esophageal cancer in US surveillance, epidemiology and end results areas. Int J Cancer 2003;105:98-100. [PubMed: 12672037]

Raida M, Sarbia M, Clement JH, Adam S, Gabbert HE, Hoeffken K. Expression, regulation and clinical significance of bone morphogenic protein 6 in esophageal squamous-cell carcinoma. Int. J. Cancer 1999;83:38-44. [PubMed: 10449605]

Rao M, Liu FS, Dawsey SM, Yang K, Lipkin M, Li JY, Taylor PR, Li B, Blot WJ, Wang GQ, Lewin KJ, $\mathrm{Yu}$ Y, Yang CS. Effects of vitamin/mineral supplementation on the proliferation of esophageal squamous epithelium in Linxian, China. Cancer Epidemiol. Biomarkers Prev 1994;3:277-279. [PubMed: 8019379]

Reen RK, Nines R, Stoner GD. Modulation of N-nitrosomethylbenzylamine metabolism by black raspberries in the esophagus and liver of Fischer 344 rats. Nutr Cancer 2006;54:47-57. [PubMed: 16800772]

Ribeiro U Jr. Posner MC, Safatle-Ribeiro AV, Reynolds JC. Risk factors for squamous cell carcinoma of the esophagus. Br. J. Surg 1996;83:1174-1185. [PubMed: 8983603]

Rijken PJ, Timmer WG, van de Kooij AJ, van Benschop IM, Wiseman SA, Meijers M, Tijburg LBM. Effect of vegetable and carotenoid consumption on aberrant crypt multiplicity, a surrogate end-point marker for colorectal cancer in azoxymethane-induced rats. Carcinogenesis 1999;20:2267-2272. [PubMed: 10590218]

Rose E. Esophageal cancer in Transkei: 1955-69. J. Natl Cancer Inst 1973;51:7-16. [PubMed: 4720888]

Schaffer EM, Liu JZ, Green J, Dangler CA, Milner JA. Garlic and associated allyl sulfur compounds inhibit N-methyl-N-nitrosourea induced rat mammary carcinogenesis. Cancer Lett 1996;102:199_ 204. [PubMed: 8603370] 
Schottenfeld D. Epidemiology of cancer of the esophagus. Semin. Oncol 1984;11:92-100. [PubMed: 6729492]

Shu YJ, Uan XQ, Jin SP. Further investigation of the relationship between dysplasia and cancer of the esophagus. Chin. Med 1981;6:39-41.

Siglin JC, Barch DH, Stoner GD. Effects of dietary phenethyl isothiocyanate, ellagic acid, sulindac and calcium on the induction and progression of $\mathrm{N}$-nitrosomethylbenzylamine-induced esophageal carcinogenesis in rats. Carcinogenesis 1995;16:1101-1106. [PubMed: 7767971]

Sons HU. Etiologic and epidemiologic factors of carcinoma of the esophagus. Surg. Gynecol. Obstet 1987;165:183-190. [PubMed: 3299822]

Souza RF. Molecular and biologic basis of upper gastrointestinal malignancy--esophageal carcinoma. Surg Oncol Clin N Am 2002;11:257-272. [PubMed: 12424849]

Stoner GD, Adams C, Kresty LA, Amin SG, Desai D, Hecht SS, Murphy SE, Morse MA. Inhibition of N'-nitrosonornicotine-induced esophageal tumorigenesis by 3-phenylpropyl isothiocyanate. Carcinogenesis 1998;19:2139-2143. [PubMed: 9886569]

Stoner GD, Gupta A. Etiology and chemoprevention of esophageal squamous cell carcinoma. Carcinogenesis 2001;22:1737-1746. [PubMed: 11698334]

Stoner GD, Kresty LA, Carlton PS, Siglin JC, Morse MA. Isothiocyanates and freeze-dried strawberries as inhibitors of esophageal cancer. Toxicol. Sci 1999;52S:95-100. [PubMed: 10630596]

Stoner GD, Morrissey DT, Heur YH, Daniel EM, Galati AJ, Wagner SA. Inhibitory effects of phenethyl isothiocyanate on $\mathrm{N}$-nitrosobenzylmethylamine carcinogenesis in the rat esophagus. Cancer Res 1991;51:2063-2068. [PubMed: 2009525]

Stoner GD, Morse MA. Isothiocyanates and plant polyphenols as inhibitors of lung and esophageal cancer. Cancer Lett 1997;114:113-119. [PubMed: 9103268]

Stoner GD, Qin H, Chen T, Carlton PS, Rose ME, Aziz RM, Dixit R. The effects of L-748706, a selective cyclooxygenase-2 inhibitor, on N-nitrosomethylbenzylamine-induced rat esophageal tumorigenesis. Carcinogenesis 2005;26:1590-1595. [PubMed: 15878914]

Stoner GD, Siglin JC, Morse MA, Desai DH, Amin SG, Kresty LA, Toburen AL, Heffner EM, Francis DJ. Enhancement of esophageal carcinogenesis in male F344 rats by dietary phenylhexyl isothiocyanate. Carcinogenesis 1995;16:2473-2476. [PubMed: 7586154]

Stoner GD, Sardo C, Apseloff G, Mullet D, Wargo W, Pound V, Singh A, Sanders J, Aziz R, Casto B, Sun X. Pharmacokinetics of anthocyanins and ellagic acid in healthy volunteers fed freeze-dried black raspberries daily for 7 days. J Clin Pharmacol 2005;45:1153-1164. [PubMed: 16172180]

Stoner GD, Chen T, Kresty LA, Aziz RM, Reinemann T, Nines R. Protection against esophageal cancer in rodents with lyophilized berries: potential mechanisms. Nutr Cancer 2006;54:33-46. [PubMed: 16800771]

Tanaka H, Kijima H, Tokunaga T, Tajima T, Himeno S, Kenmochi T, Oshiba G, Kise Y, Nishi T, Chino O, Shimada H, Machimura T, Tanaka M, Makuuchi H. Frequent expression of inducible nitric oxide synthase in esophageal squamous cell carcinomas. Int. J. Oncol 1999;14:1069-1073. [PubMed: 10339659]

Togawa K, Jaskiewicz K, Takahashi H, Meltzer SJ, Rustigi AK. Human papillomavirus DNA sequences in esophageal squamous cell carcinoma. Gastroenterology 1994;107:128-136. [PubMed: 7912679]

Tuyns AJ. Recherches concernant les facteurs etiologiques du cancer de l'oesophage dans l'ouest de la France. Bull. Cancer 1980;67:15-28. [PubMed: 7362885]

Tuyns, AJ. Epidemiology of esophageal cancer in France. In: Pfeifer, CJ., editor. Cancer of the Esophagus. CRC Press; Boca Raton, FL: 1982. p. 3-22.

Umbenhauer D, Wild CP, Montesano R, Saffhill R, Boyle JM, Huh N, Kirstein U, Thomale J, Rajewsky $\mathrm{MF}$, Lu SH. $\mathrm{O}^{6}$-methyldeoxyguanosine in oesophageal DNA among individuals at high risk of oesophageal cancer. Int. J. Cancer 1985;36:661-665. [PubMed: 4066072]

Ushida J, Sugie S, Kawabata K, Pham QV, Tanaka T, Fujii K, Takeuchi H, Ito Y, Mori H. Chemopreventive effect of curcumin on N-nitrosomethylbenzylamine-induced esophageal carcinogenesis in rats. Jpn J Cancer Res 2000;91:893-898. [PubMed: 11011116]

Wang D, Weghorst CM, Calvert RJ, Stoner GD. Mutations in the p53 tumor suppressor gene in rat esophageal papillomas induced by N-nitrosomethylbenzylamine. Carcinogenesis 1996;17:625630. [PubMed: 8625469] 
Wang LD, Lipkin M, Qui SL, Yang GR, Yang CS, Newmark HL. Labeling index and labeling distribution of cells in esophageal epithelium of individuals at increased risk for esophageal cancer in Huixian, China. Cancer Res 1990;50:2651-2653. [PubMed: 2328490]

Wang LD, Qiu SL, Yang GR, Lipkin M, Newmark HL, Yang CS. A randomized double blind intervention study on the effect of calcium supplementation on esophageal precancerous lesions in a high-risk population in China. Cancer Epidemiol. Biomarkers Prev 1993;2:71-78. [PubMed: 8420615]

Wang LD, Zhou Q, Feng CW, Liu B, Qi YJ, Zhang YR, Gao SS, Fan ZM, Zhou Y, Yang CS, Wei JP, Zheng S. Intervention and follow-up on human esophageal precancerous lesions in Henan, northern China, a high-incidence area for esophageal cancer. Gan To Kagaku Ryoho 2002;29:159-172. [PubMed: 11890101]

Wang QS, Sabourin CLK, Kresty LA, Stoner GD. Dysregulation of transforming growth factor ß1 expression in $\mathrm{N}$-nitrosomethylbenzylamine-induced rat esophageal tumorigenesis. Int. J. Oncol 1996;9:473-479.

Wang QS, Sabourin CLK, Wang H, Stoner GD. Overexpression of cyclin D1 and cyclin E in Nnitrosomethylbenzylamine-induced rat esophageal tumorigenesis. Carcinogenesis 1996;17:15831588. [PubMed: 8761413]

Wang Y, You M, Reynolds SH, Stoner GD, Anderson MW. Mutational activation of the cellular Harvey ras oncogene in rat esophageal papillomas induced by methylbenzylnitrosamine. Cancer Res 1990;50:1591-1595. [PubMed: 2406014]

Wang ZY, Wang LD, Lee MJ, Ho CT, Huang MT, Conney AH, Yang CS. Inhibition of Nnitrosomethylbenzylamine (NMBA)-induced esophageal tumorigenesis in rats by green tea and black tea. Carcinogenesis 1995;16:2143-2148. [PubMed: 7554067]

Wang GQ, Abnet CC, Shen Q, Lewin KJ, Sun XD, Roth MJ, Qiao YL, Mark SD, Dong ZW, Taylor PR, Dawsey SM. Histological precursors of oesophageal squamous cell carcinoma: results from a 13 year prospective follow up study in a high risk population. Gut 2005;54:187-92. [PubMed: 15647178]

Wargovich MJ, Woods C, Eng VWS, Stephens LC, Gray K. Chemoprevention of Nnitrosomethylbenzylamine-induced esophageal cancer in rats by naturally-occurring thioether, diallyl sulfide. Cancer Res 1988;48:6872-6875. [PubMed: 3180095]

Wattenberg LW. Chemoprevention of cancer. Cancer Res 1985;45:1-8. [PubMed: 3880665]

Wilkinson JT, Morse MA, Kresty LA, Stoner GD. Effect of alkyl chain length on inhibition of Nnitrosomethylbenzylamine-induced esophageal tumorigenesis and DNA methylation by isothiocyanates. Carcinogenesis 1995;16:1011-1015. [PubMed: 7767958]

Wynder EL, Bross IJ. A study of etiological factors in cancer of the esophagus. Cancer 1961;14:389401. [PubMed: 13786981]

Xing EP, Nie Y, Wang LD, Yang GY, Yang CS. Aberrant methylation of $\mathrm{p} 16^{\mathrm{INK} 4 \mathrm{a}}$ and deletion of p15 ${ }^{\text {INK } 5 \mathrm{~b}}$ are frequent events in human esophageal cancer in Linxian, China. Carcinogenesis 1999;20:77-84. [PubMed: 9934853]

Xu XC, Lee JJ, Wu TT, Hoque A, Ajani JA, Lippman SM. Increased retinoic acid receptor-beta4 correlates in vivo with reduced retinoic acid receptor-beta2 in esophageal squamous cell carcinoma. Cancer Epidemiol Biomarkers Prev 2005;14:826-829. [PubMed: 15824151]

Xu XC, Liu X, Tahara E, Lippman SM, Lotan R. Expression and up-regulation of retinoic acid receptor$\beta$ is associated with retinoid sensitivity and colony formation in esophageal cancer cell lines. Cancer Res 1999;59:2477-2483. [PubMed: 10344761]

Yang CS. Research on esophageal cancer in China: a review. Cancer Res 1980;40:2633-2640. [PubMed: 6992989]

Yang GZ, Li L, Ding HY, Zhou JS. Cyclooxygenase-2 is over-expressed in Chinese esophageal squamous cell carcinoma, and correlated with NF-kappaB: an immunohistochemical study. Exp Mol Pathol 2005;79:214-218. [PubMed: 16202995]

Yang WX, Pu J, Lu SH, Li FM, Guo LP. Studies on the exposure level of nitrosamines in the gastric juice and its inhibition in high risk areas of esophageal cancer. Chin. J. Oncol 1992;14:407-410.

Younes M, Henson DE, Ertan A, Miller CC. Incidence and survival trends of esophageal carcinoma in the United States: racial and gender differences by histological type. Scand J Gastroenterol 2002;37:1359-1365. [PubMed: 12523583] 
Youssef EM, Hasuma T, Morishima Y, Takada N, Osugi H, Higashino M, Otani S, Fukushima S. Overexpression of cyclin D1 in rat esophageal carcinogenesis model. Jpn. J. Cancer Res 1997;88:18-25. [PubMed: 9045891]

Yu HP, Liu L, Shi LY, Lu WH, Xu SQ. Expression of cyclooxygenase-2 in esophageal squamous cell carcinogenesis. Zhonghua Yu Fang Yi Xue Za Zhi 2004;38:22-25. [PubMed: 14989896]

Zimmermann KC, Sarbia M, Weber AA, Borchard F, Gabbert HE, Schroer K. Cyclooxygenase-2 expression in human esophageal carcinoma. Cancer Res 1999;59:198-204. [PubMed: 9892207] 


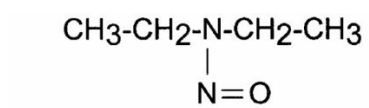

N-nitrosodiethylamine (NDEA)

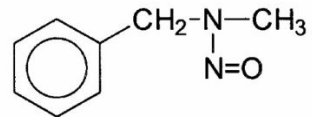

N-nitrosomethylbenzylamine (NMBA)

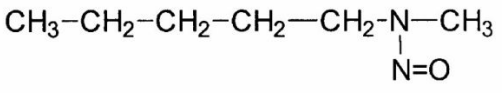

N-nitrosomethyamylamine (NMAA)

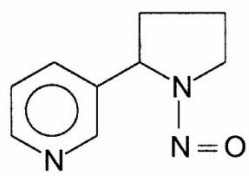

$\mathrm{N}$-nitrosonornicotine (NNN)

Figure 1.

Structures of some esophageal carcinogens (from Stoner and Gupta, 2001). 

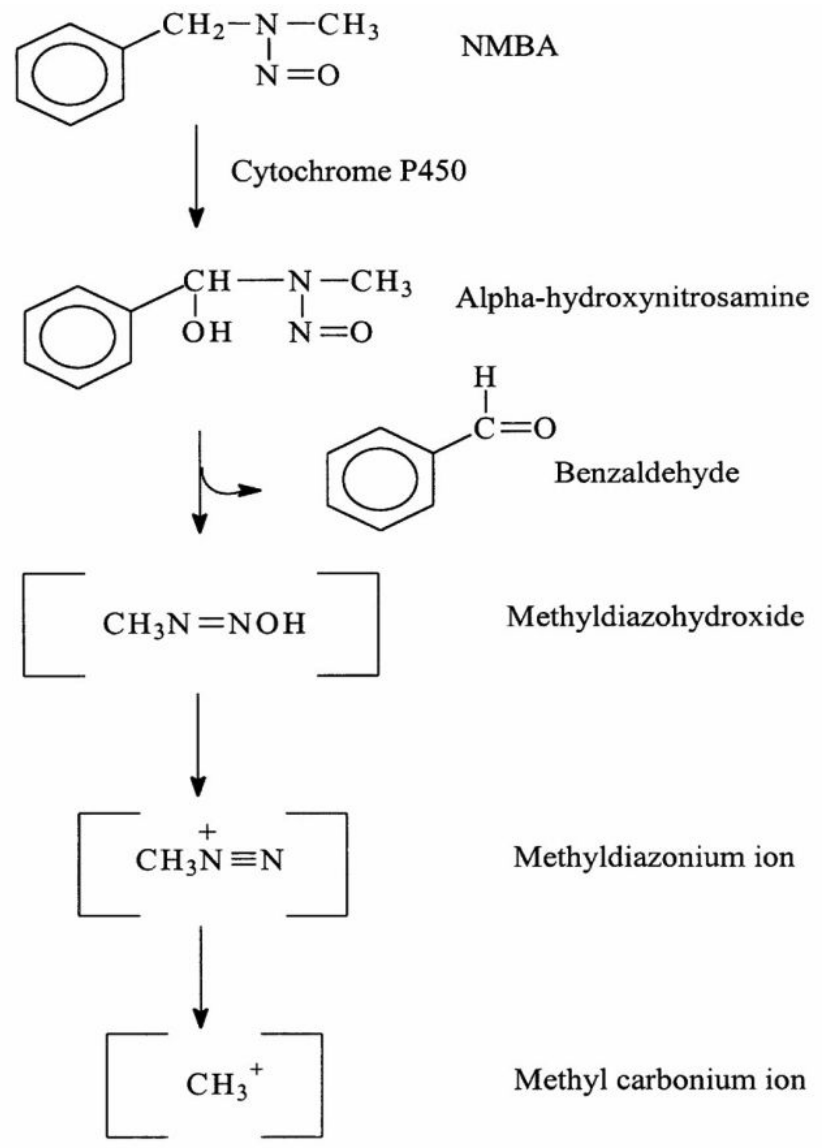<smiles></smiles>

7-methylguanine

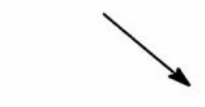<smiles>[R]n1cnc2c(OC)nc(N)nc21</smiles>

$\mathrm{O}^{6}$-methylguanine

Figure 2.

Schema for metabolic activation of NMBA (from Stoner and Gupta, 2001). 


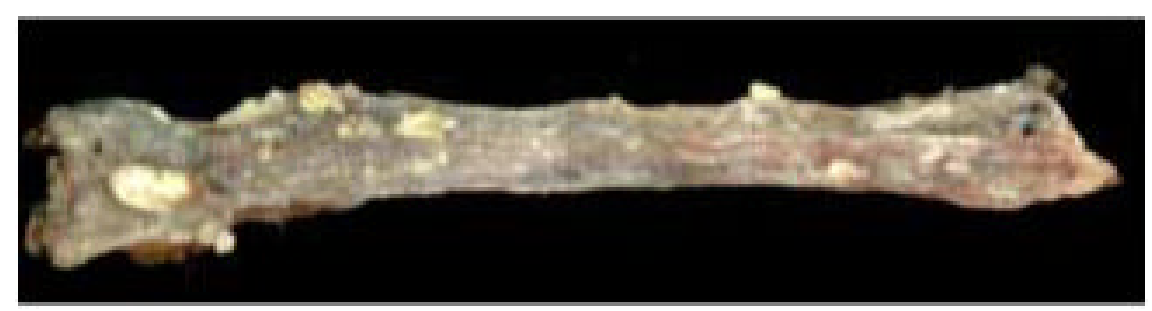

Figure 3.

Appearance of rat esophageal lesions at the termination of a 25 -wk bioassay. There are several papillomas on the surface of the esophagus. The lesion on the lower left was found to be a carcinoma upon histological analysis (from Stoner et al., 2006). 

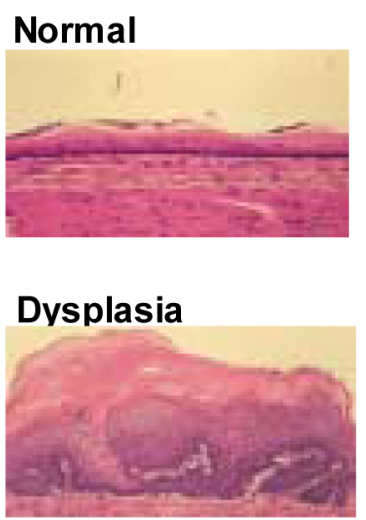

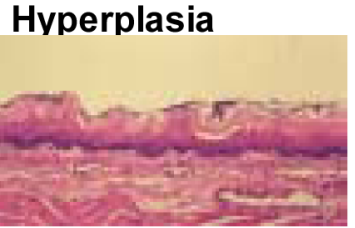

\section{Papilloma}

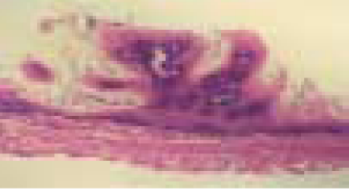

\section{Leukoplakia}

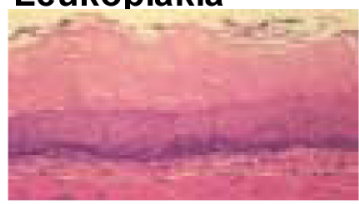

\section{Carcinoma}

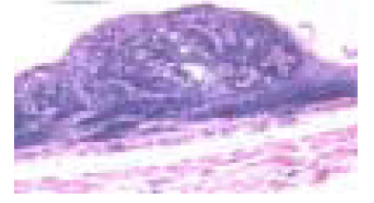

Figure 4.

Histopathology of NMBA-induced lesions in rat esophagus (from Stoner et al., 2006). 


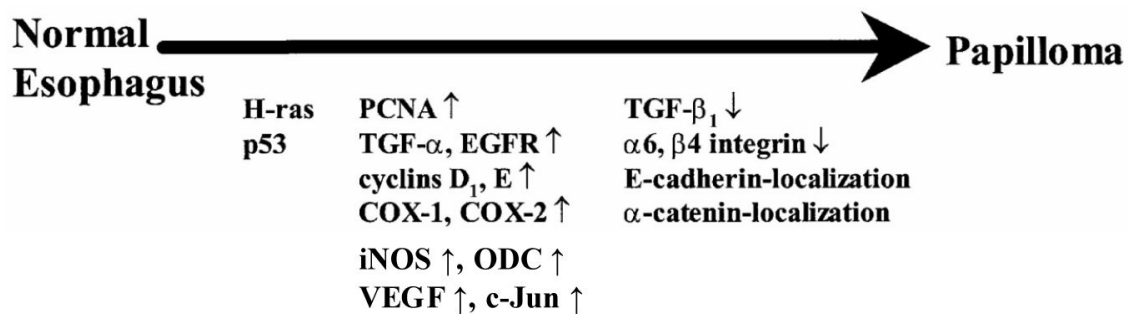

Figure 5.

Molecular events in papilloma development during NMBA-induced rat esophageal tumorigenesis (from Stoner and Gupta, 2001). 


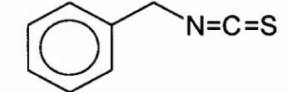

benzyl isothiocyanate (BITC)

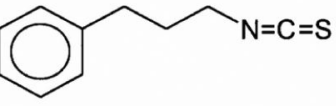

3-phenylpropyl isothiocyanate (PPITC)

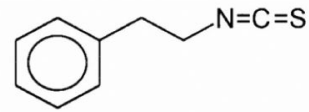

phenethyl isothiocyanate (PEITC)

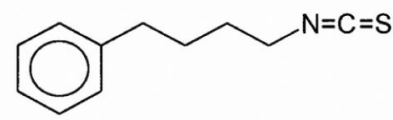

4-phenylbutyl isothiocyanate (PBITC)

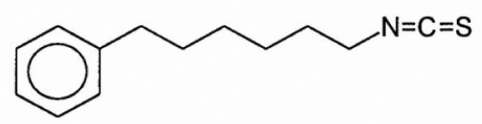

6-phenylhexyl isothiocyanate (PHITC)

Figure 6.

Structures of isothiocyanates (from Stoner and Gupta, 2001). 
Table 1

Agents that inhibit tumor initiation in the rat esophagus

\begin{tabular}{|c|c|c|}
\hline Agents & Proposed mechanism of action & References \\
\hline \multirow[t]{2}{*}{ Ellagic acid } & DNA adducts $\downarrow$ & Mandal and Stoner, 1990 \\
\hline & Phase II enzymes $\uparrow$ & Mandal et al., 1988 \\
\hline \multirow{2}{*}{ Diallyl sulfide } & $\mathrm{P} 450 \downarrow$ & Wargovich et al., 1988 \\
\hline & Phase II enzymes $\uparrow$ & Brady et al., 1988 \\
\hline Theaflavins & $?$ & Morse et al., 1997 \\
\hline \multirow[t]{3}{*}{ (-)-epigallocatechin 3-gallate (EGCG) } & Cyclin D1 $\downarrow$ & Li et al., 2002 \\
\hline & $\mathrm{COX}-2 \downarrow$ & de Boer JG et al., 2004 \\
\hline & PGE $2 \downarrow$ & Morse et al., 1997 \\
\hline \multirow[t]{2}{*}{ Curcumin } & $\mathrm{P} 450 \downarrow$ & Mori et al., 2006 \\
\hline & & Ushida et al., 2000 \\
\hline \multirow[t]{2}{*}{ Phenylethyl-isothiocyanate (PEITC) } & $\mathrm{P} 450 \downarrow$ & Stoner et al., 1991 \\
\hline & & Wilkinson et al., 1995 \\
\hline \multirow[t]{3}{*}{ Phenylpropyl-isothiocyanate (PPITC) } & $\mathrm{P} 450 \downarrow$ & Wilkinson et al., 1995 \\
\hline & & Stoner and Morse, 1997 \\
\hline & & Stoner et al., 1995 \\
\hline Phenylbutyl-isothiocyanate(PBITC) & $\mathrm{P} 450 \downarrow$ & \\
\hline
\end{tabular}


Table 2

Agents that inhibit tumor progression in the rat esophagus

\begin{tabular}{lcc}
\hline Agents & Proposed Mechanism of action & References \\
\hline Green tea, black tea (decaffeinated) & $?$ & Wang et al., 1995 \\
PBIT & CNOS inhibitor & Stoner et al, 2004 2005 \\
L-748706 & COX-2 inhibitor & Li et al., 2002 \\
Resveratrol & PGE 2 signaling & Li et al., 2001 \\
JTE-522 & COX-2 inhibitor & Fujiwara et al., 2004 \\
Irinotecan hydrochloride & Cell proliferation $\downarrow$ & \\
\hline
\end{tabular}

* PBIT: $S, S$ '-1,4-phenylene-bis(1,2-ethanediyl)bis-isothiourea 
Table 3

Freeze-dried berries as effective agents against NMBA-induced esophageal tumorigenesis.

\begin{tabular}{lcc}
\hline Agents & Proposed Mechanism of action & References \\
\hline Inhibition of initiation & DNA adducts $\downarrow$ & Kresty et al., 2001 \\
Freeze-dried black raspberry & Reen et al., 2006 \\
Freeze-dried strawberry & DNA adducts $\downarrow$ & Carlton et al., 2001 \\
Inhibition of progression & Cell proliferation $\downarrow$ & \\
& COX-2 $\downarrow$ & Chen et al., 2006 \\
Freeze-dried black raspberry & iNOS $\downarrow$ & Chen et al., 2006 \\
& VEGF $\downarrow$ & Kresty et al., 2001 \\
& c-Jun $\downarrow$ & Carlton et al., 2001 \\
Freeze-dried strawberry & PCNA $\downarrow$ & Stoner et al., 1999 \\
Brown rice and barn & Cell proliferation $\downarrow$ & Kuno et al., 2004 \\
\hline
\end{tabular}




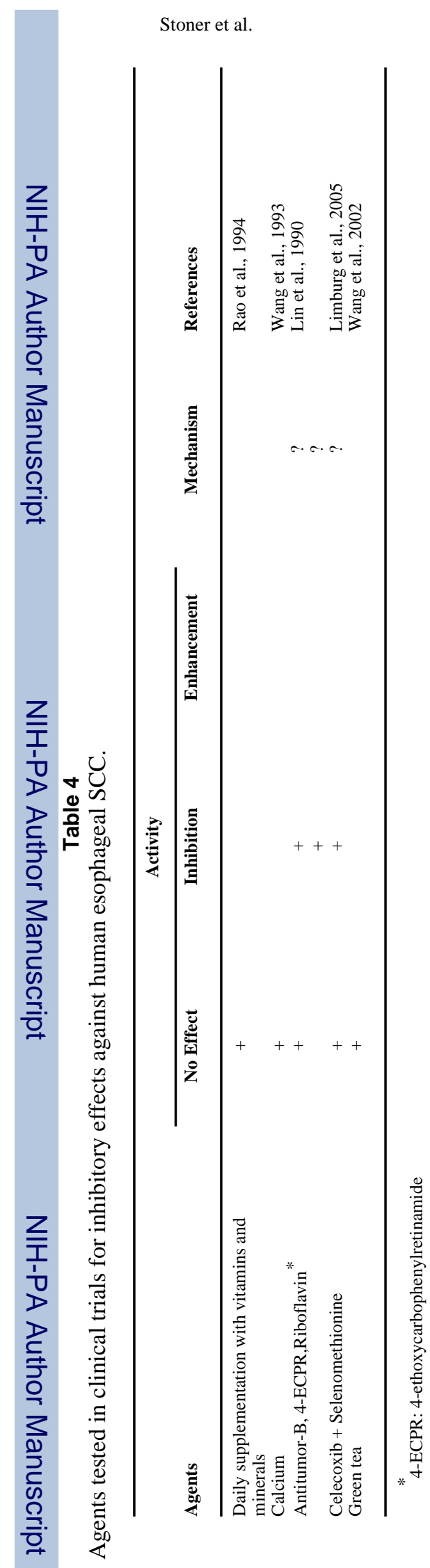

Page 27 